\title{
The strategic value of direct marketing: What are we good at? Part 1
}

Received: 20th December, 2000

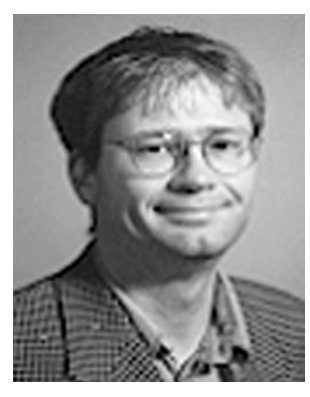

\section{Dr Alan Tapp}

is Senior Lecturer in Marketing at Bristol Business School. He has over 13 years' experience in commercial and academic marketing positions. He is the author of 'Principles of Direct and Database Marketing', and has over 20 publications in the fields of direct marketing, branding, charity marketing and, latterly, sports marketing. He has advised and trained companies as diverse as The Royal Mail and Coventry City Football Club. His major current interests are the strategic underpinnings of e-commerce, and sports marketing.

Abstract A lot of confusion is generated by the use of different terms to describe similar developments in marketing. This has led to a lack of clarity about the most important strategic imperatives impacting on direct marketing. This first of three papers takes on the task of reviewing the existing strategic position of direct marketing today. It concludes that paradigms linking direct marketing to relationship building and loyalty have a number of serious problems, and that the real strength of direct marketing lies in its abilities as an effective system for transaction marketing. The second and third papers will examine two future opportunities for direct marketing to grow. These are first the repositioning of marketing as an internal facilitator that can help other functional areas add value for customers. The final paper will look at the strategic imperatives faced by direct marketers as a result of the Internet.

\section{INTRODUCTION}

Marketers have always suffered from 'jargonitis', it is impossible to resist inventing new names for old recipes, if the product is looking tired, give it a new name. The same of course is true of marketing techniques. Although the focus here is on direct and database marketing, marketers are by no means the only culprits. Listening to UK brand marketers it is hard to distinguish 'branding' from the entirety of 'marketing' (in the USA 'branding' is confined to the creation of brand image to supplement other marketing activities — surely a more sensible division).

In the field of direct marketing, however, a mountain of jargon junk has been created: direct marketing, database marketing, loyalty marketing, retention marketing, one-to-one marketing, relationship marketing, customer relationship management, interactive marketing, responsive marketing, digital marketing and micro-marketing. In the last few years each has been trumpeted as 'the future' by the marketing press. An explanation is given, usually revolving around the idea of customers being 'treated as individuals' or 'allowing companies to understand their customers better', and a quote or two is made about how 'in five years all companies will have to do xxxx marketing, or they 
will be out of business'. A flurry of articles in the direct marketing press follow, which repeat, with quite astounding nerve, these ancient cliches dressed up as something new. 'New hypodigital-cyber-space marketing now at last we can treat our customers as individuals'. Consultants make money, while clients make astonishingly little effort to get underneath the jargon. Finally, someone with knowledge and a sense of history (usually Drayton Bird) points out wearily that it has all been heard before.

Consultants have to make money. Trade magazines have to sell circulation. But there are problems here. First, companies use jargon as a prop for lazy thinking. A mechanism for lack of thought is created. 'We need a programme for relationship marketing'. Why? 'Because everyone else has one and I read three articles about it last month'.

Secondly, the lack of definitions and huge overlaps have led to marketers having real problems communicating with each other. The word marketing itself is fraught with difficulty. Many consumer goods companies have a director of 'advertising and marketing'. A glance at any well informed textbook will confirm that advertising is one element of the communications mix, which in itself is one element of the marketing mix, which in itself is but one part of marketing. Yet advertising and marketing are presented as if they are techniques having some degree of equality. Closer examination suggests that 'marketing' in this instance often means 'sales promotion'. What happens when one executive starts talking about marketing in its broader sense to another who interprets it as a chat about sales promotion? In this discipline, many companies describe what are essentially sales pitches through the post as 'relationship marketing'. Describing transaction-driven direct marketing as relationship marketing now goes unnoticed and un-remarked.

Thirdly, marketers have become so attuned to the culture of 'new paradigms' coming along every couple of years, that the validity of any underlying principles becomes unquestioned. If these principles are not sound, then the future growth of customer databases as a business tool may be in danger.

Lastly, constant reinvention of the wheel has paralysed genuine theoretical development.

Some readers may have found this paper so far excessively critical, even cynical, about the state of marketing thinking. Others may agree with its tone. These criticisms are not, however, intended to blind marketers to the strengths of direct marketing, nor to what may be clear opportunities for future development. The point is that a morass of pseudo 'new developments' may blind marketers to what to do when a real paradigm shift comes along. It is argued here that in fact there are two genuine paradigm shifts of consequence that database marketers could see as opportunities to grow their influence within corporate strategy. The first change is the increasing shift of responsibility that marketers have from management of the 4Ps to that of facilitating the key internal processes that actually deliver competitive advantage for example customer service, or operations. The second change is the impact of the Internet on business practice. What is lacking at the moment, however, is a clear sense of what the strategic value of direct and database marketing actually is, and this needs to be established before marketers move on. The intention is that this is the first of three papers which review and debate these issues in detail. In the remainder of 
this paper the prevailing 'accepted wisdoms' of the industry will be critically evaluated. In the second paper, the author explores the possibilities for database marketing to position itself favourably within a new role for marketing. The final paper reviews and analyses the key changes wrought by the Internet, and how direct marketing may change as a result.

There are a number of theoretical approaches that have been developed, that are associated with direct marketing. The key concepts, or strategic inputs, discussed for the rest of the paper are customer management, customer loyalty, relationship marketing, one-to-one marketing, and transaction marketing.

\section{CUSTOMER MANAGEMENT}

Industry rhetoric has it that direct marketing is able to 'manage customers'. This can be done in the sense that communications with them can be managed. ${ }^{1}$ When customers contact companies, their enquiries can be dealt with effectively and efficiently because they can be put in the context of their past dealings with the company. There is plenty of theory and practical experience to support this: for example First Direct, a well-used example, provide service at a much higher level than most of their competitors, and their customer database is a vital part of this 'customer management'. These instances refer to the event of the customer initiating the contact, and how the company reacts to that. It seems common sense to this observer that customers will be favourably disposed to a firm that makes it easy to contact them. There is much less evidence, however, that customers enjoy being 'managed' in a proactive way. ${ }^{2}$ Here the idea is that the predictive qualities of customer data allow marketers to offer customers superior service by anticipating their needs, in effect removing their need to worry themselves about what they will want from the company in the future. There are, however, very few stories to illustrate successful 'proactive' customer (service) management. (This notion of proactive service should be distinguished from the concept of proactive selling to customers based on their record of past purchases — something direct marketers are arguably very good at). The argument that customers these days need help has a lot of merit. If someone could provide this author with help in choosing the right holiday for two tired adults and two energetic small children, they would receive a warm welcome. What is less welcome is the idea of being 'managed'. Pinning down future customer needs in complex markets like holidays is extremely difficult; but obtaining trust that the supplier's solution is the best one is even harder. Customers do not trust any one supplier to deliver this promise - so they do the work themselves. Customer management is only a reality when companies react to customer-initiated contact. At present, companies do not have the ability, nor do customers trust them, to execute proactive customer management.

\section{CUSTOMER LOYALTY}

There is little remaining doubt that companies with higher levels of customer loyalty generate superior returns.

Reichheld's ${ }^{3}$ and others' work on customer loyalty remains compelling evidence that loyalty is important. What is much less clear is the role of direct and database marketing in achieving this difficult goal. For the most part, customers are not loyal in most emotional senses of the word. ${ }^{4,5}$ If loyalty is defined as customers giving firms time to get things right if they get it wrong, 
it then follows that emotional loyalty is more powerful than, say, financial loyalty, or 'lock in' inertia. Yet the latter, being easier to deliver, is overwhelmingly what businesses use to try and keep their customers. Marketers rely on customers' willingness to put up with lousy service because they cannot face changing to another supplier. The point here though is to ask what evidence there is that database-driven marketing initiatives have a significant impact on loyalty levels. The answer seems to be that at present it is not possible to be certain, because lamentably few companies bother with a control cell to test the power of their 'loyalty programmes'. There is now, however, a fair amount of academic research $^{6-8}$ that disputes whether loyalty schemes, magazines, or any other tactical initiative makes much difference. Loyalty schemes are undoubtedly powerful as conduits for data gathering, which so conventional wisdom has it, companies will use to target customers individually. Unfortunately, there is little evidence that this has happened in any substantive way.

The one way in which data-driven direct marketing can improve customer retention is through renewal of contracts through timely communications. ${ }^{9,10}$ Knowing when a customer's car insurance has expired, or when their subscription is up for renewal, can enable a direct marketer to improve customer convenience, and perhaps to make the offer that bit more attractive based on a good track record in the past. Customer data give the company power: it knows when the customer will be in the market, so the offer is timely.

In summary, emotional loyalty is probably a reality only when personal interactions take place. Direct marketing has limited power in generating loyalty. When purchases are predictive, however, for example insurance sectors, customer data make the act of buying more convenient.

\section{RELATIONSHIP MARKETING}

Over the last decade, surely little has generated more misunderstanding in the marketing field than the relationship marketing/direct marketing overlap. The two terms have been used

interchangeably by agencies, the press, consultants and clients, to the dismay of both traditional direct marketers and relationship marketers. The latter would both argue that there are in fact substantial differences between the two entities.

The roots of relationship marketing lie firmly in business-to-business markets and service industries and the term was first coined by Berry. ${ }^{11}$ In business-to-business markets, a good deal of evidence has been gathered which supports the view that personal relationships will add value to and supplement economic reasons for buying. ${ }^{12}$ In consumer markets there is very little evidence that the same value is placed on relationships, but there is uncertainty about this because there is even less evidence of any substantial attempts actually to create relationships with customers. Meanwhile, asking customers what they feel about relationships with companies is as likely to provoke puzzlement or maybe derisive laughter than anything more positive. O'Malley and Tynan agreed, stating that it is 'generally accepted that the characteristics of consumer [mass] markets make relationship building difficult if not impossible. These characteristics include the large numbers of anonymous consumers, limited opportunity for interpersonal interactions, and the prevalence of low value/low involvement purchases. As such, the mix management 
[transactional marketing] paradigm was argued to be far more appropriate in this context'. ${ }^{13}$

In the light of these doubts, the idea of customer data and subsequent direct marketing being used to build relationships should be examined. Perhaps in high involvement sectors direct approaches may be used to offer a service that the consumer may find valuable. The good work done by Botton Village Charity is an example of this. ${ }^{14}$ Their work may well be relationship building, and is a rare example of personalised, tailored service, but it is perhaps the face-to-face charity-donor interactions that build genuine relationships, rather than database marketing, although the latter will undoubtedly help. Another positive example is the use of customer data at the point of delivery to deliver tailored service to privileged individuals. Hotel chains may attempt to be proactive with high-value business guests by offering them certain rooms, drinks on arrival, and so on. The question that is not often asked within the direct marketing community, however, is this: what is the added value of tailoring the service? Would the customer be satisfied with a non-personalised, but high quality pampering in which they got extra privileges, but delivered reactively, based on their say so rather than recorded transaction data? It is suggested here that the key use of customer data is in identifying their high value to the firm, rather than helping deliver tailored service.

These rare positive examples of data-driven marketing are swamped by the hugely negative consumer reaction to direct marketing generally. The biggest sectors - financial services, mail order, telecommunications and even the charities - make little or no effort genuinely to build relationships. It can be concluded that there is an almost total lack of hard evidence that suggests direct marketing can build relationships with consumers. More fundamentally, the entire concept of relationship marketing in consumer markets appears to be seriously flawed.

\section{ONE-TO-ONE MARKETING}

Perhaps the ultimate manifestation of superior direct and database marketing is one-to-one marketing. This movement was led with fantastic clarity by Peppers and Rogers. ${ }^{15,16}$ The theory was and still remains elegant and convincing. Putting it into practice has, however, proved a lot more difficult. As Mitchell has said, there is not much evidence to date of one-to-one marketing becoming a practical reality. ${ }^{17}$ Businesses are seemingly finding the operational reality of learning about customers at an individual level, then delivering personalised service simply too difficult, even if limited to their highest value customers. More fundamentally, there is also a lack of research or industry evidence that customers desperately want personalised products or services, although this is likely to differ by sector.

\section{TRANSACTIONAL MARKETING}

The roots of direct marketing lie in the mail order industry. ${ }^{18}$ Throughout the expansion of direct marketing into hitherto direct-free sectors, the basics of mail order techniques have changed little. A culture of testing has helped establish a set of principles which can teach the general marketer much about consumer behaviour: what people respond to, what kind of offers tend to work better, how products should be presented creatively to maximise response and so on. The point is that this success story refers to 
transactional marketing — selling. This is marketing-mix marketing by direct means. The additional role of the database is also clear - it allows firms to segment by value and by customer need, and to 'predictively' target so as to maximise the probability of response. It also allows marketers to develop statistical profiles of the most profitable customers, and hence target new prospects more efficiently.

These good, well-developed, profitable techniques have been appropriated by other sectors. From charities to retail to financial services and beyond, the story is the same: behind the hype management fads and buzzwords, most proactive direct and database marketing is selling. Good old-fashioned transaction marketing: making a buck, cutting a deal, selling off stock, tactical promotions so that marketers 'hit target', next month's market share figures .... This transaction mentality still dominates many if not most sectors. Traditional practitioners would argue that the lessons about direct marketing's role are clear. Forget about relationship marketing, customer management or loyalty.

Fundamentally, direct marketing is a practical tool that gets things done...it competes in the real world with personal selling, retail outlets and traditional advertising, and often 'wins'.

\section{CONCLUSION}

This efficiency at transaction marketing is what has driven direct marketing's growth. The temptation then is to leave it at that. Perhaps many direct marketing 'old timers' would call upon the management consultants, the academics, the commentators and say 'leave us alone to get on with what we do best: making money'. By leaving it at that, however, an opportunity to raise the profile of database marketing within business is being missed. Database and direct marketers at present occupy relatively low levels of power and influence in the strategic decision making of most companies. But marketers' work puts them very close to customers, certainly compared to non-marketing functions. This closeness gives database marketers an opportunity to influence strategic direction and market orientation of the entire company through information provision and analysis. Most large companies have 'analysis' departments, or similar. Their role, to provide management information, may typically be at a relatively junior level. Typically, it is the finance department that will control the provision of higher level information from which the company makes its key decisions. But does this have to be the case? There is no reason why the marketing department should not improve its influence and its agenda — customers - with better information that links customer behaviour with company profitability. In the next paper of this series, the author outlines one possible scenario of how database marketers could use the current interest by companies in 'knowledge management' to improve their position of influence.

\section{References}

1 Gamble, P., Stone, M. and Woodcock, N. (1999) 'Up close and personal? Customer relationship marketing@ work', Kogan Page, London.

2 For example, Evans, M., O'Malley, L. and Patterson, M. (1995) 'Direct marketing: Rise and rise or rise and fall?', Marketing Intelligence and Planning, Vol. 13, No. 6, pp. 16-23.

3 Reichheld, F. F. (1996) 'The loyalty effect', Bain \& Co.

4 Hartley, M. (1997) 'It wouldn't stop me going somewhere else: Supermarkets and their loyalty cards', 31st annual conference, Academy of Marketing, 8-10th July, Manchester.

5 Lynch, J. E. and Michell, P. (1997) 'Supermarket loyalty cards: Low involvement relationship marketing', 31st annual conference, Academy of Marketing, 8-10th July, Manchester. 
6 Uncles, M., (1996), 'Loyalty, behaviour - the direct marketing issues', presentation to IDM Educators Day, Wembley, London, UK.

7 Uncles, M. (1994) 'Do you or your customers need a loyalty scheme?', Journal of Targeting, Measurement and Analysis, Vol. 2, No. 4, pp. 335-350.

8 Tapp, A. (1998) 'Principles of direct and database marketing', F. T. Pitman, London.

9 McCorkell, G. (1997) 'Direct and database marketing', Kogan Page, UK.

10 Tapp (1998) op. cit.

11 Berry, L. L. (1983) 'Relationship marketing', in Berry, L. L., Shostack, G. L. and Upah, G.D. (eds) 'Emerging perspectives on services marketing', American Marketing Association, Chicago, pp. 25-28.

12 Payne, A. (1995) 'Advances in relationship marketing', Butterworth Heinemann, Oxford.

13 O'Malley, L. and Tynan, C. (1999) 'The utility of the relationship metaphor in consumer markets: A critical evaluation', Journal of Marketing Management, Vol. 15, pp. 587-602.

14 Burnett, K. (1992) 'Relationship fundraising', White Lion Press, London.

15 Peppers, D., Rogers, M. and Pine, J. (1995) 'Do you want to keep your customers forever?', Harvard Business Review, March-April, pp. 103-114.

16 Rogers, M. and Peppers, D. (1993) The one-one future', Piatkus, USA.

17 Mitchell, A. (2000) 'In one-to-one marketing, which one comes first?', Interactive Marketing, pp. 354-368.

18 McCorkell (1997) op. cit. 